\title{
Proyecto Silos: difusión y revitalización del patrimonio industrial abandonado
}

\begin{abstract}
En 2013 se consolida un colectivo cultural sin ánimo de lucro, Proyecto Silos. Emerge promoviendo el debate sobre los posibles usos de un silo que se encontraba en estado de abandono. El grupo lo integran, principalmente, arquitectos y estudiantes de arquitectura que, desde ese primer proyecto hasta el día de hoy, se proponen difundir, poner en valor, rehabilitar e investigar el patrimonio industrial agrario desatendido. El camino: crear una red de redes, un espacio global de intercambio sobre silos que revierta positivamente en los comunidades rurales.
\end{abstract}

Alejandro Bocanegra Cayero I Proyecto Silos

URL de la contribución <www.iaph.es/revistaph/index.php/revistaph/article/view/3746>

El planteamiento inicial de este proyecto es poner en valor y rehabilitar el patrimonio industrial, y en concreto el agrario, entendiendo que aún está poco considerado a pesar del importante papel que desempeñó en el desarrollo socio-cultural de nuestra historia reciente. Se trata de un equipo de trabajo e investigación integrado por españoles, portugueses e italianos, que realiza labores de documentación, catalogación, propuestas de restauración/consolidación y rehabilitación de bienes muebles e inmuebles.

La base de este colectivo se apoya en tres ejes fundamentales. El primero está relacionado con la cultura, por las labores de investigación, difusión y sensibilización sobre patrimonio industrial; también es un proyecto social, por la implicación de las personas y la contribución al desarrollo rural; y el tercer pilar es de tipo ético y sostenible, por la revalorización y aprovechamiento responsable de los bienes y recursos existentes, y por la generación de otros nuevos, que beneficien a las personas y al medio ambiente.

La organización se consolidó en el año 2013 con el objetivo inicial de debatir posibles usos para un silo en concreto, de tipo D5 y en estado de abandono. Debido a que no se trataba de un caso aislado pronto surgió la inquietud de estudiar el estado y situación de los silos en general, las causas que habían llevado a su abandono en el pasado, y las posibilidades para albergar nuevos usos en un futuro.
Para ello se creó la plataforma web (www.proyectosilos. com) donde se comparte el contenido generado en el colectivo. Se trata de un recurso autogestionado y en constante desarrollo con el que se pretende crear un nexo entre un público especializado (mediante la publicación de vídeos, conferencias, documentación bibliográfica..) y un público general (exposiciones fotográficas, infografías, fotomontajes, talleres para niños...). La plataforma se apoya en aspectos relacionados con la percepción y el diseño, volcando la información de la forma más dinámica y accesible posible (libre y gratuita, bajo licencia Creative Commons).

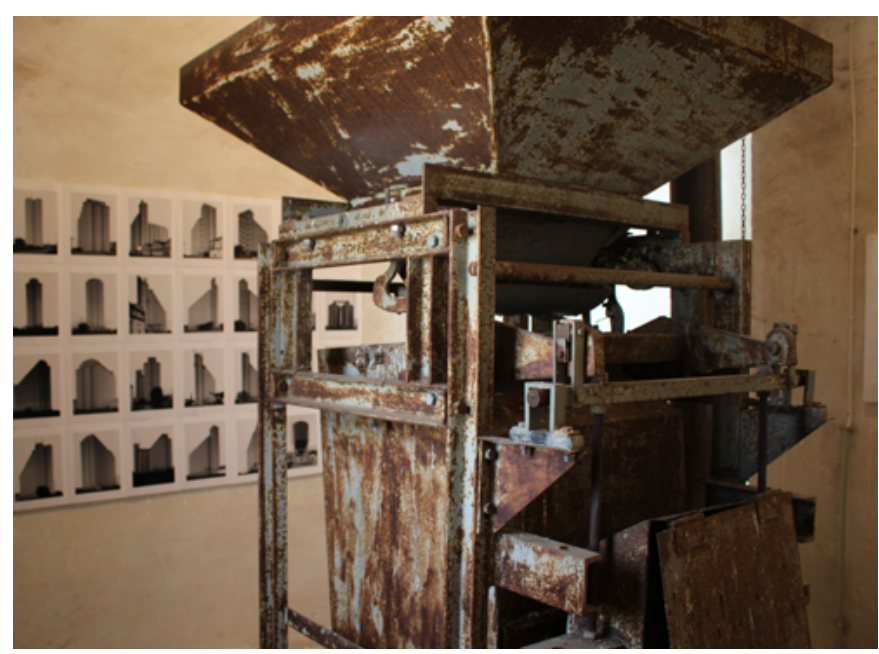

Exposición Silos do Alentejo | foto Proyecto Silos, titular de todas las imágenes de la contribución 
Varios de los estudios y propuestas que se han realizado en Proyecto Silos se han presentado mediante comunicaciones y pósteres a diferentes exposiciones y congresos. Se pretende que el contenido generado sea didáctico, y aunque en materia de difusión y puesta en valor se trate de un proyecto global, las propuestas y proyectos están enfocados al contexto rural. Desde el colectivo se busca que las iniciativas repercutan positivamente en las localidades y no sólo en el propio silo a intervenir. Se trata de superar el hito y convertir a estos elementos en motores de desarrollo local.

El grupo organizó en 2014 las I Jornadas de Patrimonio Industrial Agrario (Silos a debate), en las que se discutió, junto a expertos en patrimonio, paisaje, arquitectura y urbanismo, sobre el futuro de estos edificios. El encuentro se desarrolló durante los días 26 al 28 de septiembre en el interior del silo de Villanueva del Fresno (Badajoz), albergando en cada una de sus salas actividades paralelas. Durante este tiempo el edificio sirvió para el intercambio, divulgación y aproximación cultural. Muchos vecinos de la localidad pudieron por primera vez subir al edificio, entender su uso y funcionamiento, así como participar en los diferentes debates y proyectos que se estaban acometiendo. El resultado de las jornadas, además de en la web del proyecto, puede consultarse a través del código QR instalado mediante azulejo en la fachada del propio edificio.

La coordinación de Proyecto Silos es compartida. Las decisiones se toman de forma asamblearia, a través de la red, mediante videoconferencias. En ellas participan tanto coordinadores/as y colaboradores/as del proyecto. Es ahí donde se toman realmente las decisiones. Mediante la creación de grupos de trabajo, se reparten tareas, o se proponen otras nuevas. La asignación de las tareas se realiza de forma voluntaria, a través de una lista de objetivos en la que cada integrante puede escoger aquella que más se adecúe a sus intereses y capacidades.

El proyecto está abierto al patrocinio y colaboración por parte de cualquier administración u organización pública o privada. Aunque hasta el momento se ha autofinanciado mediante las cuotas de sus integrantes y la venta

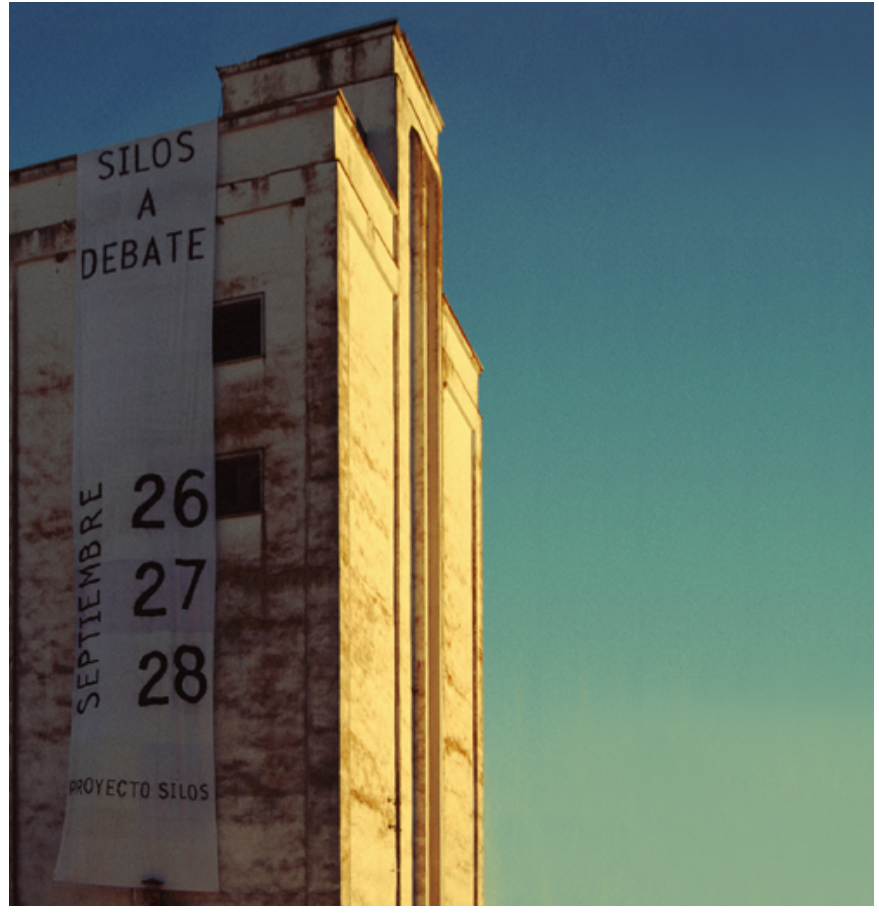

Jornadas Silos a debate en Villanueva del Fresno. Badajoz | foto Proyecto Silos

de merchandising relacionado, necesita del apoyo de otras instituciones para el mantenimiento y desarrollo web, así como el material divulgativo, publicaciones y actividades culturales generadas. Y está abierto a la participación de cualquier persona interesada, independientemente de su ámbito académico o profesional.

\section{Más información}

- www.proyectosilos.com

- info@proyectosilos.com 